\title{
What's wrong with Modern Money Theory: macro and political economic restraints on deficit-financed fiscal policy
}

\author{
Thomas Palley* \\ Independent analyst, Washington, DC, USA
}

The essential claim of Modern Money Theory (MMT) is sovereign currency issuing governments, with flexible exchange rates and without foreign currency debt, are financially unconstrained. This paper analyses the macroeconomic arguments behind that claim and shows they are suspect. MMT underestimates the economic costs and exaggerates the capabilities of deficit-financed fiscal policy. Those analytic shortcomings render it poor economics. However, $M M T$ 's claim that sovereign governments are financially unconstrained is proving a popular political polemic. That is because current distressed economic conditions have generated political resistance to fiscal austerity, and MMT fits the moment by countering the neoliberal polemic that government lacks fiscal space because it is akin to a household.

Keywords: Modern Money Theory (MMT), budget deficits, job guarantee program

JEL codes: $E 00, E 12, E 40, E 58, E 60$

\section{INTRODUCTION: A BRIEF OVERVIEW OF MMT}

Recently, there has been a burst of interest in Modern Money Theory (MMT). ${ }^{1}$ MMT is associated with a small overlapping group of economists at the University of Missouri, Kansas City, and the Levy Economics Institute, NY, USA. Leading contributors include Warren Mosler, Stefanie Kelton, and Randall Wray. Australian economist William Mitchell is also a leading contributor. An early comprehensive statement of MMT is provided in Wray's 1998 book Understanding Modern Money: The Key to Full Employment and Price Stability. ${ }^{2}$

* Email: mail@thomaspalley.com.

1. The burst of interest is evident in extensive media references. Stephanie Kelton, a leading MMT proponent, was an economic advisor to US Senator Bernie Sanders. It is also evidenced by the fact that MMT has prompted critical debunking responses from leading mainstream economists, such as Ken Rogoff (2019) and Greg Mankiw (2020), who usually disdain engagement with non-mainstream economists.

2. The founding manifesto statement of MMT is Mosler (1996). Wray (1998) represents the first comprehensive statement and, in my view, is the clearest. Wray (2015) provides a further elaborated comprehensive statement that incorporates additional material on sectoral balance macroeconomic accounting, money creation accounting, and exchange rate regimes. As discussed further in the text of this article, a major problem with these elaborations is that they obscure the essence of MMT by conflating it with other issues and controversies in macroeconomics. 
The essence of MMT is that sovereign currency issuing governments, with flexible exchange rates and without foreign currency debt, are financially unconstrained. That is because government has the power to create money to pay its bills, including its debts. The only constraint on government is the availability of real resources. If the resources are available, government can buy them and pay for them by creating money. If they are not available, creating money to buy goods causes inflation. ${ }^{3}$

According to MMT, a corollary implication of that is taxes are not needed to finance spending. Instead, the role of taxes is to drain money out of the economy after government has spent it, in order to manage aggregate demand and keep it in line with the available supply of resources.

As shown in Figure 1, MMT rests on a triad of arguments concerning:

1. the macroeconomics of money- and bond-financed budget deficits;

2. the employer of last resort or job guarantee program; and

3. the history of money.

The 'meat and potatoes' component is the macroeconomics of money- and bondfinanced budget deficits. It describes MMT's view of how government finance works, why taxes are not needed to finance spending, and why government is financially unconstrained.

The second leg of the triad is the job guarantee program (JGP), whereby the government acts as employer of last resort (ELR). That component is the policy component, and it claims to show how the economics of MMT can be harnessed by policy to deliver non-inflationary full employment.

The third leg of the triad is the history of money, which is invoked to enlist monetary history on MMT's side. The historical claim is that money's origins are chartal. That means modern money came into being because government issued it as a form of IOU token to pay for goods, and those tokens were accepted because they could be used to pay taxes.

The paper analyses and dissects the three legs of the triad and shows they all involve suspect economic arguments. MMT focuses on government's technical

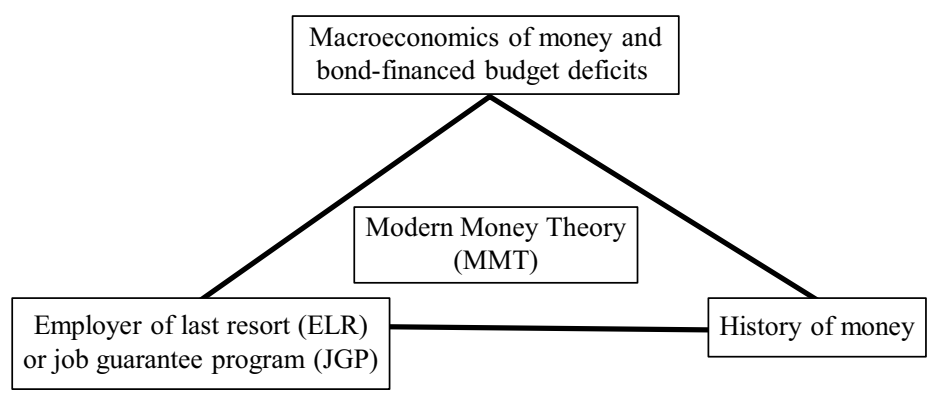

Figure 1 Overview of Modern Money Theory (MMT)

3. For instance, Nersisyan and Wray (2020) write MMT 'demonstrates that a government like that of the US does not, in fact, face financial constraints ... . MMT's proponents have always maintained that government spending is limited only by available economic capacity.' Nersisyan and Wray (2010) debate the issue of limits to government debt and conclude 'sovereign government is not constrained financially, which means it can never face a solvency issue' (p. 19) and 'inflation is the true limit to government spending not lack of financing' (p. 20). 
capacity to issue money, which seemingly renders government financially unconstrained. However, budget deficits can have costly ramifications measured in terms of government's policy objectives, which can deter government from deficit spending. MMT neglects those costly ramifications, leading it to underestimate the economic costs and exaggerate the capabilities of deficit-financed fiscal policy.

The conclusion is MMT's analytic shortcomings render it poor economics. That said, its printing press approach to government spending is proving a popular political polemic, countering neoliberal polemic which justifies fiscal austerity by describing government as akin to a household.

\section{SOME CLARIFYING PRELIMINARIES}

Before turning to the substance of the argument, some preliminary ground clearing is necessary. That is because a major difficulty debating MMT is the tendency to conflate important but unrelated issues. That is evident in the tendency for debate to bleed into a broader debate about macroeconomics, rather than sticking with what is specifically unique to MMT. Before getting to what is specifically unique to MMT it is therefore useful to identify some issues that are not at stake.

\subsection{Keynesianism is not the issue}

The MMT debate is not about Keynesianism and the Keynesian principle of demanddetermined output. Proponents of MMT adhere to the Keynesian theory of effective demand-determined output, but so too do MMT's Keynesian critics - including this author.

\subsection{The effectiveness of deficit-financed fiscal policy is not the issue}

The MMT debate is also not about the effectiveness of deficit-financed fiscal policy. That is clear from consideration of the IS-LM model which dominated Keynesian macroeconomics through to the mid 1970s. In that model, policymakers can push the economy to full employment via expansionary fiscal policy. Bond-financed fiscal stimulus shifts the IS schedule in an expansionary direction, while money-financed stimulus shifts both the IS and LM schedules in an expansionary direction. If the central bank is targeting the interest rate, the IS shifts in an expansionary direction and the LM schedule is horizontal. That illustrates how fiscal policy effectiveness and the ability to use fiscal policy to obtain full employment are not unique to MMT, and MMT actually uses the same Keynesian logic as the IS-LM in explaining fiscal policy effectiveness.

\subsection{Money- versus bond-financed fiscal deficits is not the issue}

Nor is the issue money or bond finance. As shown above, both money- and bondfinanced fiscal policy are effective in Keynesian theory, and money-financed deficits are more expansionary because they deter any proclivity to interest rate crowding-out from increased bond supplies. Current institutional arrangements have fiscal deficits financed by bonds. However, if the central bank is targeting interest rates or engaging 
in quantitative easing $(\mathrm{QE})$, there is some implicit money-financing via central bank bond purchases. The money- versus bond-financing question is an institutional design and policy choice question, with MMT supporters tending to advocate that the fiscal authority be given direct access to the central bank's power to issue money. That is a political economy issue which has long been understood, and MMT takes a particular stance. Whether deficits are bond- or money-financed is not germane to MMT's larger theoretical claim about sovereign governments being financially unconstrained. ${ }^{4}$

\subsection{The need for fiscal stimulus is not the issue}

Likewise, the need for fiscal stimulus is not the issue. MMT proponents are strong advocates of fiscal stimulus and have advocated more stimulus, even as the US economy approached unemployment rates traditionally associated with full employment (Kelton et al. 2018). They also advocate a fiscal policy architecture based on Lerner's $(1943 ; 1951)$ functional finance construct. Those are issues of policy choice rather than fundamental monetary theory. Many Keynesians have also advocated similar stimulus policies, yet they disagree with MMT's monetary theory claims. That shows the design and stance of fiscal policy is not the core issue. However, since MMT has gained media prominence via its fiscal policy recommendations, that has contributed to a misunderstanding whereby fiscal policy effectiveness and design are misinterpreted as being the theoretical issues raised by $\mathrm{MMT}^{5}$

\subsection{Stock-flow consistent modeling, endogenous money, and private debt are not the issues}

Stock-flow consistent modeling, endogenous money, and private sector debt are also not the issues. These are all features of the macroeconomic framework used by MMT proponents, but they are also all part of the Post-Keynesian consensus and long predate MMT. The interest in stock-flow consistent macroeconomics traces back to 1960s Neo-Keynesian economics (Christ 1968) which explicitly focused on the implications of budget deficits for the debt stock and money supply. MMT obscures the issue by tending to claim these features as its own (Lavoie 2019), and by even presenting them as the substance of MMT. For instance, Tymoigne and Wray (2015) respond to criticisms of MMT with 20 pages describing the injection-withdrawal monetary accounting relations connecting different sectors within the economy, rather than addressing the criticisms regarding policy constraints.

4. According to MMT, if bond-financing runs into trouble, government can simply switch to money-financing without consequence. In common with standard Keynesian macroeconomics, MMT does recognize that money- and bond-financing are different in that bond-financing entails an interest payment, which is expansionary as it increases household income. It is also the case that payment tends to be regressive as wealthier households own the larger part of the government debt.

5. That said, since fiscal policy is center stage in the public debate, it is worth clarifying its place. For 30 years, a substantial segment (perhaps even a majority) of mainstream economists inclined against fiscal policy effectiveness. As Keynesianism retreated within the mainstream economics profession, that diminished the Keynesian voice regarding fiscal policy effectiveness. MMT has contributed to resurrecting that voice. 


\subsection{Macroeconomic sectoral balance analysis is not the issue}

Lastly, macroeconomic sectoral balance analysis is not the issue. MMT proponents emphasize such analysis (Wray 2015; Mitchell et al. 2019), but such analysis long predates MMT. The Keynesian economist James Tobin (1963) was an early pioneer who showed how government deficits implied private sector surpluses. Likewise, the British Keynesian economist Wynne Godley (1999) used sectoral balance analysis to explain emerging financial instability in the 1990s US economy. The important point is sectoral balance analysis follows from the national income accounts, was pioneered by Keynesian economists, and MMT adds nothing to it per se. ${ }^{6}$

\section{THE MACROECONOMICS OF MONEY- AND BOND-FINANCED BUDGET DEFICITS $^{7}$}

The previous section highlighted what MMT is not about. It is now time to engage what it is about. The 'meat and potatoes' theoretical claim of MMT is that sovereign currency issuing governments, with flexible exchange rates and without foreign currency debt, are financially unconstrained and do not need taxes to finance their spending. That is because such governments can always pay by 'printing' money. In modern parlance, printing money means electronically creating money via central bank keyboard entries that credit agents with money claims against the central bank. As Wray (1998, p. 78) writes:

The important thing to notice is that the Treasury spends before and without regard to either previous receipt of taxes or prior bond sales ... . The implication is that tax payments do not 'finance' government spending but they create a demand for currency and impact reserves.

Additionally, MMT claims government spending is essential as it is the only way to get money into the system, and it is impossible to pay taxes without money in the system. ${ }^{8}$ Thus, Wray (1998, p. 80) writes:

In principle, then, the government first spends fiat money (to purchase goods, services, and assets or to provide 'transfer payments', which retires a government liability). Once government has spent, then the fiat money is available to be transferred to the government to meet tax liabilities. As a matter of logic, the public cannot pay fiat money to the government to meet tax liabilities until the government has paid out fiat money to the public.

Together, those two propositions support MMT's fundamental claim that 'monetarily sovereign governments have a flexible policy space unconstrained by hard financial limits' (Tymoigne and Wray 2015, p. 24).

Given the above, MMT recommends that government should spend until the economy reaches full employment and all workers who want a job are employed. At that stage, government can raises taxes and drain money from the economy to prevent inflation. That policy recommendation is an application of Lerner's principle of functional

6. Sectoral balance analysis is an accounting exercise. The interesting question is: what is the theory that explains the accounting outcomes? Keynesian macroeconomics provides one theoretical perspective. MMT adds nothing to the theoretical explanation of sectoral balances and relies exclusively on long established Keynesian logic.

7. Many of the arguments in this section are drawn from Palley (2015a; 2015b).

8. That seems to tacitly suggest MMT is supportive of money-financed deficits. Unfortunately, as noted earlier, in practice MMT proponents are ambiguous over whether budget deficits should be money- or bond-financed. 
finance (Lerner 1943; 1951). A corollary proposition is that the interest rate is discarded as a tool of stabilization policy and parked. The MMT recommendation is to park the interest rate at zero (Wray 1998, p. 87; 2007, p. 22; Forstater and Mosler 2005).

Essentially, MMT recommends that deficit-financed fiscal policy replace monetary policy for purposes of reaching and sustaining full employment. More specifically, government spending (including spending on guaranteed jobs) should be used to drive the economy to full employment, and thereafter taxes should be adjusted to prevent inflation. ${ }^{9}$ Taxes are not needed to finance spending because money is unbacked fiat (so-called modern money) and can always be created by government to pay for resources.

Figure 2 provides a taxonomy of the macroeconomic critique of MMT which is the focus of the rest of this section. As can be seen, the critique is extensive and multifaceted, and it identifies a mix of sins of omission and commission. MMT's simplistic construction of the economy omits critical features that impact the economic cost and effectiveness of budget deficits. At the same time, its simplistic construction includes features and policy recommendations that are highly problematic.

\subsection{Recycled and oversimplified Old Keynesian economics}

As regards the left-hand panel in Figure 2, the critique of MMT is that it is a mix of old and new, the old is correct and well understood, while the new is substantially wrong' (Palley 2015b, p. 45). MMT's main macroeconomic claim to fame rests on its declaration regarding government's ability to finance spending without recourse to taxation owing to its ability to issue money. In fact, government's ability to create

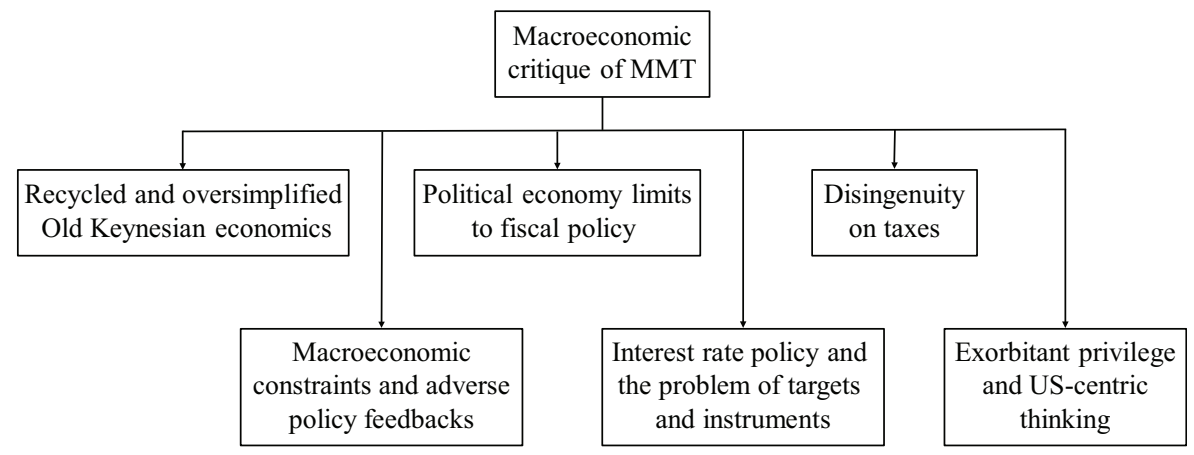

Figure 2 Taxonomy of the macroeconomic critique of MMT

9. Recently, MMT proponents have begun walking back the idea that functional finance is central to MMT (Wray, comments at the Eastern Economic Association, March 2019). The purpose of the walk-back appears to be to deny that taxes are needed at full employment to neutralize inflationary excess demand caused by excessive government spending. Three points follow. First, it is fundamentally dishonest to deny the long-standing central role of functional finance in MMT's argument, as evidenced in the early contribution of Kelton (1999). Second, walking back the need for taxes means MMT has now shifted to arguing that inflation control should be conducted via rationing, price controls, and other administrative measures (Nersisyan and Wray 2019). Third, it is illustrative of the difficulty understanding and debating MMT as its proponents repeatedly change their positions. 
money to finance spending has long been widely recognized by all economists, who have also long recognized that ability gives government considerable extra financial and policy space. ${ }^{10}$ For instance, using a stock-flow consistent IS-LM model with a fully specified government budget restraint, Blinder and Solow (1973) show how money-financed budget deficits can move an economy to full employment. The logic is simple. Money-financed budget deficits create financial wealth, which increases aggregate demand (AD) via the consumption wealth effect, thereby moving the economy to full employment. ${ }^{11}$

Old Keynesian economics clearly recognized the capacity of government to finance spending without taxes. That said, there are two 'new' components to MMT. The first is the claim that government has to spend to inject state money into the system to pay taxes. ${ }^{12}$ The second concerns the macroeconomics of government finance, with MMT claiming that government's ability to create money means government is financially unconstrained and can costlessly push the economy to full employment.

As regards injecting state money to pay taxes, MMT is strictly wrong with its claim that the public cannot pay taxes until government has first spent. In fact, the central bank is the source of state money (so-called outside or high-powered money). It can inject outside money into the system by buying existing government bonds, buying private sector assets, or by lending to private banks. Moreover, under the current system, the central bank will increase the outside money stock by paying interest on existing money balances. That means government spending is not the only way to get state money to pay taxes into the system.

Furthermore, a central bank that is targeting interest rates is obliged to provide whatever outside money the private sector needs, including money to pay its taxes, to prevent interest rates from rising. That is because the short-term interest rate is the price of state money, and a shortage of state money will place upward pressure on the short-term interest rate. ${ }^{13}$

As regards the macroeconomics of government finance, MMT focuses on accounting and stock-flow relations. There are two points to make. First, those accounting and stock-flow relations have long been understood by Keynesian and

10. Keynesian economists tend to emphasize how the ability to create money provides fiscal policy space to manage aggregate demand. Classical macroeconomists tend to emphasize how it enables government to collect seignorage via inflation, thereby providing another source of tax revenue that can be an economically efficient way of raising revenue. In this author's view, both groups are right.

11. Bond-financed deficits are analytically slightly more complicated because the increase in bond supplies can potentially increase interest rates. That was the basis of the 'crowding-out' debate of the 1970s, but it turns out bond-financed deficits still move the economy to full employment absent perverse effects. Moreover, it is a non-issue if the central bank targets interest rates, in which case the central bank implicitly monetizes the deficit to prevent the increase in bond supplies from raising interest rates.

12. For instance, Wray (1998, p. 80) writes: 'In principle, then, the government first spends fiat money .... Once the government has spent, then the fiat money is available to be transferred to the government to meet tax liabilities. As a matter of logic, the public cannot pay fiat money to the government to meet tax liabilities until the government has paid out fiat money to the public.'

13. Michell (2019) has recently made similar observations. However, he claims MMT does not say government spending is needed to pay taxes. That is contradicted by MMT's written record. The argument that spending is needed to pay taxes has been an important part of MMT's rhetoric claiming that taxes do not finance spending and government is financially unconstrained. 
Neo-Keynesian economists. ${ }^{14}$ Second, and more importantly, MMT's accounting framework has a static 'moment in time' character and is bereft of behavioral content. That lack of dynamics and behavioral content leads to fundamentally flawed claims regarding the macroeconomic effects of money-financed deficits and government's ability to use deficit finance to secure its policy goals (about which more below).

The point of departure of MMT's macroeconomic analysis is the government budget constraint, and MMT objects to its being called a constraint as if government were a household. However, that is a terminological objection. Moreover, Old Keynesians also recognized it was not a constraint and referred to it as the budget identity or budget restraint (Christ 1968). Its significance is it tracks the impact of budget outcomes on stocks of inside money and government debt, and it holds for all governments. ${ }^{15}$

The critical theoretical question is: what are the macroeconomic impacts of changes in those stocks and the changes in AD that they finance? MMT sees the effects of increasing government financial obligations as entirely benign, and policymakers can use the financial space to costlessly boost demand and push the economy to full employment. There are no negative consequences from increasing government financial obligations; no conflicts with other policy objectives; and no policy implementation problems. In contrast, Old Keynesians had a more complicated view of the economy in which negative consequences, policy conflicts, and policy implementation problems are possible. ${ }^{16}$

As shown below, MMT's macroeconomic policy assertions follow from its oversimplified and incomplete Keynesian analysis. The lack of a dynamic economic model with behavioral content is a glaring professional failure. Unfortunately, instead of addressing that failure, MMT proponents have responded by claiming critics either do not understand it or have misrepresented it.

The difficulty of confronting MMT about those failings is compounded by its practice of walking back its positions and adopting those of its critics without acknowledgment. Examples include replacing the full employment threshold model of inflation (Wray 1998) with the Keynesian Phillips curve model, and also recognizing that capital controls may be needed to contain international economic forces that can potentially disrupt fiscal policy. Recently, Kelton (2019) has slipped in another long-standing Keynesian argument that stability of the debt-GDP ratio requires that the nominal interest rate be less than the nominal rate of growth $(i<g)$. In doing so, she tacitly admits another financial constraint on government and continues the walking-back process. On the one hand, the walking-back process is reasonable: on the other hand, it dissolves MMT's claims regarding government being financially unconstrained.

\subsection{Macroeconomic constraints and adverse policy feedbacks}

The second panel in Figure 2 concerns macroeconomic constraints and adverse policy feedbacks which MMT ignores and which undermine its claim that government is

14. For instance, those accounting and stock-flow relations were at the heart of the Yale School macroeconomics research program developed by James Tobin in the 1960s (Tobin 1969; 1982).

15. Sovereign governments can issue both money and bonds, whereas non-sovereign governments can only issue bonds.

16. Indeed, it can reasonably be argued that Old Keynesians were too benign in their assessment of deficit-financed policy. At the theoretical level, Old Keynesian models do a poor job of modeling private credit markets, which excludes one of the principal channels whereby adverse effects of budget deficits might show up. Likewise, the Keynesian Phillips curve approach to inflation can be argued to be too benign. 
financially unconstrained. Though government has the formal technical ability to finance all spending by creating money, that technical ability is a will-o'-the-wisp because government is constrained by the reality of the potentially high economic costs of doing so. Using the 'printing press' to finance spending can create subsequent problems that leave government worse off measured in terms of its objective function.

In the real world, economic policy and policy outcomes are subject to multiple economic concerns and constraints. Those include concerns about government bond rates, private credit market long-term interest rates, financial market stability, the balance of payments and the exchange rate, the inflation constraint imposed via the Phillips curve, and policy implementation and policy credibility constraints. Those various concerns and constraints impact the economic costs and effectiveness of deficit-financed fiscal policy. However, they are all absent in MMT's oversimplified theoretical framework. In particular, MMT's framework is static and has little to say about how policy affects expectations of the future, and how expectations of the future have important immediate consequences.

\subsubsection{Financial markets, the complex of interest rates, and asset prices}

Government is likely to face significant financial market blowback if financial markets believe it is engaging in excessive money issue. In particular, long-term interest rates will tend to rise if financial market participants anticipate risks of future financial turmoil or higher future inflation. Current financial market conditions are affected by expectations about the future, which means the future is always already here and in the present. Consequently, inflationary bias in MMT's reliance on money-financed deficits will creep into present financial market conditions long before full employment.

It is sometimes claimed that government can set the long-term bond interest rate, just as it sets the short-term money market interest rate. The argument is government can buy or sell long-term bonds to set the long-term interest rate in the same way as it does for the short-term rate. However, if private agents deem the bond rate too low given inflation expectations created by money-financed deficits, the government bond market will shrivel, in the sense of fewer private agents being willing to buy government bonds. More importantly, bond market repression does not prevent interest rates rising in private credit markets, and they may even overshoot owing to unfavorable expectations caused by money-financed fiscal policy. Consequently, the combination of money-financed deficits and bond market repression can disrupt private credit flows, and thereby disrupt economic activity. Furthermore, owing to expectations, those disruption effects can emerge in advance of full employment. However, once again, such effects are absent in MMT because it ignores expectations and treats private credit markets as irrelevant.

Increases in the money supply can also potentially cause asset price bubbles. That is because some of the money injected into the circular flow of expenditure and income leaks into the financial circuit via the process of saving (Palley 1998), where it is directed to bidding up asset prices. Bubbles are unstable and subject to abrupt crashes owing to changes in sentiment and expectations. When they crash they can cause major economic disruption, as illustrated by the global financial crisis of 2008. Bubbles can also develop independently of full employment. Those features give policymakers good reason to prevent them, which constrains policy. For instance, bond-financing of deficits may be preferable to money-financing to the extent that bond-financing is less likely to promote 
financial market bubbles. However, bond-financing raises its own concerns with adverse interest rate effects and debt sustainability. Such considerations are absent in MMT's analysis because it is silent on asset price formation, the effect of asset prices, and the impact of budget deficits on asset prices.

Interestingly, the effect of budget deficits on credit and asset markets will likely depend on current conditions and expectations of future outcomes, with expectations being influenced by the nature of the policy regime. That type of effect illustrates the importance of the Lucas (1976) critique for understanding financial market responses to deficit-financed fiscal policy. Such concerns with the bond market's reaction and psychology were also central in Keynes's critique of Lerner's functional finance view and its assertion that money-financed spending could effortlessly solve the Keynesian macroeconomic problem (Aspromourgos 2014). However, such effects are again absent in MMT, which explains why MMT fails to recognize them.

\subsubsection{Exchange rate and trade balance concerns}

Budget deficits can also have significant adverse exchange rate and balance of payments effects, especially money-financed deficits. Expansionary budget deficits bleed into the trade deficit via their impact on income and the demand for imports. The deterioration of the trade deficit then tends to depreciate the exchange rate. The exchange rate will also tend to depreciate owing to adjustment of international portfolio positions. Exchange rate depreciation can then cause inflation, which further aggravates the depreciation problem. Additionally, under certain circumstances, exchange rate depreciation can trigger macroeconomic contraction (Krugman and Taylor 1978).

Keynesian macroeconomics emphasizes international constraints, and they are often summarized in models via the idea of a balance of payments constraint. However, owing to its US-centric focus, MMT largely ignores such problems which are a first-order constraint on economic policy in many countries. Moreover, in the past the US has also been subject to such constraints, and it could confront them again in the future.

To the extent MMT discusses international constraints, it dismisses them with the facile assertion that a floating exchange rate resolves them. However, a floating exchange rate has its own adverse financial and inflation complications. Furthermore, if the balance of payments constraint is structural, it can be unresponsive to exchange rate depreciation owing to either induced inflation effects or low import and export elasticities.

\subsubsection{Inflation and the Phillips curve}

Another problem is that inflation does not work as MMT describes. According to MMT, government should run money-financed budget deficits until all real resources are employed. At that stage, the economy becomes supply-constrained and policy should step on the budget brake to prevent emergence of inflation. Inflation is therefore presented as a 'threshold' problem, but that is not how inflation develops in the real world. Instead, the economy consists of multiple sectors, and some hit the full employment barrier before others. Consequently, inflation starts bubbling up before there is aggregate full employment, and government lacks the capacity to target its demand injections sector by sector and market by market. Contrary to the claims of 
Wray (1998, p. viii), it is not easy to have full employment without inflation, and policymakers confront an inescapable inflation-unemployment trade-off. ${ }^{17}$

Replacing the threshold model of inflation with a Phillips curve introduces the familiar policy challenges of trade-offs and inflation expectations. As argued earlier, those expectations are influenced by policy regime and they are likely to be adversely impacted by adoption of an MMT policy regime. Furthermore, in an economy with a backward-bending Phillips curve (Rowthorn 1977; Akerlof et al. 2000; Palley 2003), excessively expansionary money-financed deficits could cause inflation expectations to jump to the positively sloped portion of the Phillips trade-off where higher inflation generates higher unemployment.

Interestingly, and not well advertised by proponents of MMT, such concerns prompted Lerner $(1977 ; 1978)$ to significantly qualify his system of functional finance. In particular, Lerner was concerned about the problem of inflation posed by full employment, which prompted him to develop his wage-increase permit (WIP) plan whereby the government would limit inflation by issuing tradeable permits allowing wage increases. ${ }^{18}$ Ironically, MMT proponents tend to be especially dismissive of the problem of inflation despite Lerner's concern with inflation at full employment.

\subsubsection{Inflation, interest rates, and the policy mix}

Introducing a Phillips curve introduces inflation, and inflation affects the real interest rate, which then unravels MMT's approach to interest rate policy. MMT recommends parking the nominal interest rate at zero (Wray 1998, p. 87; 2007, p. 22; Forstater and Mosler 2005), which implies real rates would fall as the economy moves up the Phillips curve. ${ }^{19}$ That potentially creates an unstable situation in which higher inflation creates lower real interest rates which in turn drives higher inflation. The converse problem would hold if the economy moved down the Phillips curve as real interest rates would rise with unemployment, potentially causing even higher unemployment.

Recognizing that interest rates matter introduces the familiar fiscal-policy-monetarypolicy mix problem which was a central concern of Old Keynesians, and which is another concern that is entirely neglected by MMT. The greater the emphasis on fiscal looseness, the more the need to raise real interest rates to avoid excessive AD. However, higher interest rates negatively impact investment and growth. Consequently, a government that is concerned about growth and future living standards will be concerned about

17. Wray (1998, p. viii) writes: 'The primary policy conclusion that comes out of this analysis is, perhaps, shocking, but it can be stated simply: it is possible to have truly full employment without causing inflation. This will appear to be a desirable goal, but a preposterous claim; no self-respecting Keynesian, monetarist or supply-sider would allow herself to entertain such hopes. But if the analysis here is correct - and it goes without saying that I am sure it is then the logical conclusion is that we can move immediately to full employment with enhanced stability.'

18. The scheme is modeled on the logic of tradeable pollution permits. Just as the aggregate issue of pollution permits limits the amount of permissible pollution, so too the aggregate issue of wage-increase permits (WIPs) would limit the amount of aggregate permissible wage inflation.

19. Wray (2007, p. 22) writes: 'Given these considerations, as well as the arguments advanced by Keynes, a monetary policy rule is preferred - set the overnight rate at zero, and keep it there. A properly programmed tin robot ought to do the trick.'. 
budget deficits and their implications for interest rates, which in turn means it is financially constrained and concerned about bond market sentiments.

The problematic of the policy mix also connects with another Neo-Keynesian concern regarding portfolio crowding-out (Haliassos and Tobin 1990, pp. 893-894), which is different from Monetarist crowding-out. Monetarist crowding-out concerns the impact of deficit-financed fiscal policy on AD and output. Portfolio crowdingout concerns the impact of deficit-financed fiscal policy on wealth composition. In particular, if the demand for wealth is finite and government financial obligations are net wealth, government deficits can crowd-out private capital accumulation by increasing the supply of government wealth that must be held in private portfolios.

Restoring activist interest rate policy does not save MMT. Indeed, the opposite is true. If policymakers are concerned about interest rates, they need to be concerned about the state of the interest rate spectrum, of which the policy rate is part. That means policymakers need to be concerned about financial market conditions, which implies government is not financially unconstrained. Furthermore, maintaining an interest rate target requires issuing government financial obligations, and government needs to be concerned about the impact of that issuance on AD and financial markets. Again, government is not unconstrained.

\subsubsection{Summing up: the problems are far more than just inflation}

Putting the pieces together, the implication is sovereign governments' ability to use deficit-financed fiscal policy (be it money- or bond-financed) is limited by market constraints and reactions which impose costs on governments. The problems are far more than just the possibility of inflation. The bite of market constraints, market reactions, and induced policy costs varies according to economic conditions and policy regime. They also vary by country (about which more below). That is not to say sovereign governments have no space to use deficit- (and money-) financed fiscal policy, but it does say governments are not financially unconstrained.

\subsection{Political economy limits to fiscal policy}

The third panel in Figure 2 concerns the political economy failings of MMT. Those political economy failings fundamentally challenge the viability of Lerner's (1943; 1951) functional finance approach and suggest an MMT policy regime could even create economic instability.

As noted earlier, according to Neo-Keynesian logic, budget deficits drive the economy to full employment by increasing wealth and AD. That makes it critical there be institutional arrangements for closing the deficit once full employment is reached to avoid inflationary excess. However, MMT relies on a highly simplified and implausible political economy in its attempt to address that problem. Thus, it assumes taxes can be abruptly and precisely raised at full employment to contain excess demand, when the reality is taxes are politically contested and difficult to raise. Long ago, Friedman (1961) argued that fiscal policy was impractical for 'fine-tuning' stabilization policy owing to inside (decision) and outside (implementation) lags. Those lags mean policy implementation is likely to be poorly timed, so much so that it could amplify the business cycle rather than dampen it.

The Friedman critique of fiscal policy concerns 'timing' of policy actions. It can be augmented to include a 'public choice' critique based on politicians' aversion to 
raising taxes and cutting spending. ${ }^{20}$ That aversion stands to reinforce the problem of fiscal policy timing. Additionally, it stands to impart an inflationary bias and gradually ratchet up government spending as a share of GDP. That is relevant because MMT recommends increased spending to stimulate the economy below full employment, and higher taxes once full employment is reached. Over successive cycles MMT's policy frame is likely to be destabilizing. ${ }^{21}$ Absent budget discipline, spending and deficits would tend to ratchet upward owing to the political attraction of deficit-financed spending (especially money-financed deficit spending) and the political aversion to higher taxes. Yet MMT reduces budget discipline by arguing the central bank should be under the direct control of the fiscal authority which is encouraged to use moneyfinanced deficits. ${ }^{22}$

Another political economy critique (Lavoie 2014) is that central banks and fiscal authorities are institutionally separated in most economies, but MMT ignores this and treats them as a unified decisionmaker. The separation is usually justified on public choice grounds that politicians have an inclination to inflationary monetary populism, and separation of fiscal and monetary powers helps prevent that. MMT ignores the separation, invoking an 'as if' argument.

Two implications follow. First, as Lavoie (2014) notes, the current system does not support MMT's policy claims as the system is not structured as needed. Second, if the system were changed and structured as required by MMT, financial markets would likely shift to expecting an increased likelihood of inflationary monetary populism owing to MMT's policy frame. That would cause asset prices to fall and interest rates to rise.

The latter critique links to MMT's comprehensive failure to take account of the impact of expectations of policy on economic behaviors and financial markets. Expectations about the future impact current private sector decisionmaking, which implies the inflationary bias in MMT's fiscal policy assignment will impact present conditions long before inflation accelerates or full employment is reached. Given that, it is easy to envisage how an MMT regime could even generate economic instability. An untimely money-financed fiscal stimulus could raise concerns about financial instability or inflation expectations, thereby raising current market interest rates and prompting the need for further fiscal stimulus. That we do not see such patterns today may be because policy is not constructed according to MMT's institutional and policy recommendations. ${ }^{23}$

20. The aversion to raising taxes is one reason why monetary policy is the preferred instrument of fine-tuning stabilization policy. Just as monetary policy is delegated to central banks to facilitate policy decisionmaking, so too tax policy could be delegated to a board of tax experts, but that would be a profoundly undemocratic turn.

21. Those features explain why it is difficult to use fiscal policy to 'fine-tune' the economy, except for tax and spending programs that operate automatically and counter-cyclically. That makes the ELR/JGP critical for MMT as it is a form of counter-cyclical automatic stabilizer but, unfortunately, it is fraught for other reasons.

22. Ironically, proponents of MMT appear to be exhibiting exactly this type of ratchet spending effect. Initially, the focus of MMT's spending recommendations was the provision of an ELR job guarantee program (Wray 1998). To that has now been added Medicare for all, expanded social security, free college tuition (plus forgiveness of existing college debt), and a Green New Deal (Palley 2019).

23. Ironically, an MMT policy regime could breathe life into the notion of expansionary austerity. Thus, an MMT regime would tend to raise private sector interest rates. Abandoning the regime would tend to lower them. Note, it is the change of regime that is important rather than specific government spending cuts or tax increases. 


\subsection{Interest rate policy and the problem of targets and instruments}

The fourth panel in Figure 2 concerns interest rate policy, and MMT proponents argue the nominal interest rate should be parked at zero. The above political economy critiques (regarding fine-tuning and public choice biases) speak to the difficulty of using fiscal policy to stabilize the business cycle and deliver full employment. For those reasons, monetary policy (that is, interest rate policy) is widely viewed as the preferred instrument for delivering on those goals, yet MMT discards it by parking the interest rate which may introduce instability (Palley 2015a, pp. 17-18). ${ }^{24}$

That policy assignment failing is compounded by MMT's specific interest rate policy which may also create an instrument shortage problem. In a static economy, policymakers aim to hit full employment, but they must also have a balanced budget to prevent an exploding money-output ratio. If fiscal policy is constrained by minimum spending requirements and maximum acceptable tax rates, it may not be possible to achieve both targets if the interest rate is off the table and set equal to zero (Palley 2015b, pp. 53-54).

More generally, in a Tinbergen (1952) world economic policymakers have many targets and tend to be short of instruments. Those targets include full employment, business cycle stabilization, low inflation, government debt sustainability, financial market stability, the exchange rate, and the trade balance. Yet MMT discards interest rate policy, which is an important tool of macroeconomic management. Worse yet, by parking the nominal interest rate at zero or near zero, MMT would likely encourage financial instability and exacerbate problems that are already in play from printing money.

\subsection{Disingenuity about the role and necessity of taxes}

The fifth panel in Figure 2 concerns MMT's disingenuity about the role and necessity of taxes. That disingenuity has been emphasized by Marxists and left-wing economists (Henwood 2019; Sawicky 2019) and is succinctly summarized by Brueing (2019): 'The real point of MMT seems to be to deploy misleading rhetoric with the goal of deceiving people about the necessity of taxes in a social democratic system.'

Marxist economists have focused on MMT's blithe dismissal of the problematic of taxes. As noted above, if the economy reaches full employment (however defined), taxes become necessary to restrain $\mathrm{AD}$ and prevent inflation. Consequently, the reality is government programs ultimately have to be paid for via taxes. If taxes are ultimately necessary to finance government programs, delivering those taxes requires the appropriate politics be in place. Those politics inevitably involve class conflict. Viewed in that light, Marxists argue MMT is deficient on two counts. First, it is evasive about the ultimate necessity of taxes. Second, it fails to recognize that tax outcomes are ultimately shaped by class conflict and depend on power relations, which in turn are substantially determined by the economic fundamentals of capitalist economies. From a Marxist perspective that makes MMT a new political strategy for finessing the politics of austerity rather than a new economic theory.

That tax deception is facilitated by MMT's static 'moment in time' economic analysis. At a moment in time, particularly when unemployment is high, it may look as if

24. Jayadev and Mason (2018) examine the assignment problematic in a dynamic context where output is growing and the budget challenge is redefined as maintaining debt sustainability. Once again, political economy considerations speak to assigning interest rate policy to the output target and fiscal policy to the debt sustainability target. 
taxes are unnecessary as resources are available, financial constraints on government are currently non-binding, and government can create money. However, those conditions will change. Taxes become unavoidable as the economy moves along the Phillips curve and inflation increases owing to greater resource demands, and taxes may even be needed earlier if other economic constraints kick in earlier.

MMT's disingenuity about taxes was evident in recent US discussions about an expanded welfare state. MMT proponents advocate for national health insurance (Medicare for All), expanded retirement income (social security), and free university tuition. Their claim is those programs can be had because of government's ability to print money. The reality is the needed resources would have far exceeded the economic capacity available at the date of discussion (Palley 2019). Consequently, the program spree would have generated excess demand and inflation unless paid for by taxes and fees.

The important point is that taxes are needed to pay for ongoing programs, and money-financed deficit spending is at best a temporary free lunch. ${ }^{25}$ Moreover, as many programs are intended to have a significant redistributive component, taxes are also needed to accomplish redistribution. Consequently, taxes are unavoidable for both macroeconomic capacity reasons and microeconomic redistribution reasons.

More generally, it is pure semantics whether taxes raise money to finance government spending, or taxes destroy money in order to create the space for reissue of money to finance spending. Taxation and spending occur simultaneously, and taxes are an intrinsic part of the system and cannot be done away with. Even when the economy is far from the full employment/inflation target, taxes are needed to finance the vast bulk of spending. Money-financed budget deficits provide some space at the margin for temporary additional spending, which eventually either has to be cut or be financed by some combination of taxes and borrowing when the economy's constraints bite. ${ }^{26}$

\subsection{Exorbitant privilege and US-centric thinking}

The sixth panel in Figure 2 concerns exorbitant privilege and the US-centric nature of MMT's theorizing. MMT represents itself as a general theory applicable to all sovereign governments. However, the self-evident inability of most sovereign governments to pursue its policy recommendations promotes widespread skepticism among economists from those countries. In response, MMT tends to revert to justifying its claims by appeal to the US (and, to a lesser degree, to economies of other countries whose currencies serve as international reserve currencies). Here too MMT falls apart as the above arguments apply to all governments, including the US government, albeit in differing degrees. As regards the US, that is evidenced by the problems experienced by the US dollar in the 1970s which was an era of high inflation.

That said, it is easy to misperceive the fiscal capacity of the US government as confirming MMT. That is because the US government superficially appears to have the

25. As is widely known, in a growing economy there is always some permanent free lunch in that the money stock can grow at the rate of GDP growth plus inflation. As shown by Cagan (1956), inflation is a two-edged sword. On the one hand, faster inflation increases the free lunch by increasing the inflation tax rate on money holdings. On the other hand, faster inflation reduces the demand for money, thereby reducing the base on which the inflation tax is levied. 26. If the economy is away from steady state, and the inflation rate and the money-GDP ratio are both rising, then there will be additional temporary financial space along the traverse to the steady state. 
power to conduct policy as prescribed by MMT. However, that appearance is false. The US conveys a misleading impression because it is the beneficiary of the fact that the world operates on a de facto dollar standard. That gives rise to the phenomenon of 'exorbitant privilege' (Eichengreen 2011), whereby the US benefits from issuing dollars to meet the global economy's dollar needs. That makes it look as if the US economy conforms to MMT when, in fact, a completely different phenomenon is at work. Moreover, retaining the benefits of exorbitant privilege subjects the US to policy limits and responsibilities. ${ }^{27}$

The reality that the US is, in principle, potentially subject to the same type of constraints as other governments is evidenced by the economic history of the 1970s. That era was a period of dollar weakness, and it shows the US can also be subject to biting financial constraints.

\section{JOB GUARANTEE PROGRAM (JGP) $)^{28}$}

The second leg of MMT's triad of arguments in Figure 1 is the proposal for a JGP, whereby the central government would offer work to any who applied (that is, act as employer of last resort). In principle, the JGP is completely separable from MMT and can be considered as a stand-alone program on the basis of its own merits. However, for MMT, the JGP is central because it is how policy is supposed to harness government's power to create money so as to deliver productive non-inflationary full employment.

The JGP can be thought of as an attempt to create an automatic stabilizer in the spirit of Lerner's $(1943 ; 1951)$ functional finance approach to macroeconomic policy. Lerner's approach has government engage in expansionary 'discretionary' fiscal policy until the economy reaches full employment, at which time policymakers are supposed to step on the fiscal policy brakes. The JGP aims to create an 'automatic stabilizer' version of functional finance. That is because, theoretically, there should be no spending on JGP jobs at full employment since all workers are employed in the private sector and normal government jobs. Consequently, spending would automatically taper off.

Though JGP spending automatically adjusts, a JGP is not an anti-inflation buffer stock mechanism, contrary to the claims of Mitchell and Mosler (2001). A JGP sets a wage floor which acts as a buffer stock mechanism guarding against deflation. It does so by drawing labor supply off the market as unemployment increases. However, it does not mitigate inflation by adding additional labor supply as unemployment decreases. The buffer against inflation is the supply of available labor and that is the same, with or without a JGP. ${ }^{29}$

In theory, the JGP proposal has significant macroeconomic benefits including generating a particular type of full employment, providing another automatic counter-cyclical

27. The requirements for being a reserve currency issuer are discussed extensively by Epstein (2019). The important implication is that the capacity to reap the benefits of currency issuance depends on special institutional circumstances and is not available to all sovereign currency issuers, in contradiction of MMT.

28. Many of the arguments in this section are drawn from Palley (2018b).

29. That contrasts with a commodity buffer stock mechanism in which previously stored commodity supplies are released for sale when the price hits the 'ceiling' price. One caveat is if the JGP increases labor supply by keeping workers attached to the labor market, which would damp inflation. 
stabilization mechanism, preserving the skills of unemployed workers by keeping them in jobs, and providing society with the benefits of the output produced by JGP workers.

However, it also has significant downsides which MMT proponents dismiss. ${ }^{30}$ One downside is the cost of a JGP, which could displace other needed programs (though MMT denies that by assumption, because it asserts government is financially unconstrained). A second downside is the potential to displace private sector production if workers prefer JGP jobs. A third downside is JGP jobs can be used to undercut public sector unions and enforce workfare in place of welfare. In effect, a JGP could be used by a neoliberal government as a double-edged sword to undercut public sector employment from above and undercut worker rights from below. A fourth downside is some JGP jobs might be characterized as 'make work,' and that could be used as political fodder by neoliberals in their war on government.

The JGP proposal also augments inflation worries that are already inherent in MMT's money-financed approach to fiscal policy. The main problem is a JGP sets a real wage floor for the entire economy, thereby implicitly introducing inflation indexation. As the economy approaches full employment, inflation will tend to rise in accordance with Phillips curve logic. That will trigger a higher nominal JGP wage, and raising the nominal wage floor will tend to spread inflation throughout the economy. If private sector firms fail to match the JGP nominal wage increase, workers will start to drift toward JGP jobs, causing a contraction of private sector output that could even potentially cause stagflation. The JGP is intended to be a non-inflationary automatic fiscal stabilizer. Yet closer inspection shows its implicit indexing may also render it an automatic inflation destabilizer. ${ }^{31}$

Furthermore, to the extent that a JGP delivers quasi-full employment, it will also tend to exacerbate income distribution conflict inflation which emerges at full employment (Kalecki 1943). That is because it would remove or diminish the threat of labor pricing itself out of work, thereby potentially increasing wage demands. The problem of full employment conflict inflation is generic, but a JGP would exacerbate it. Indeed, a JGP could trigger such inflation even earlier by emboldening wage demands earlier in the business cycle. There is no easy solution to that problem, which explains Lerner's $(1977 ; 1978)$ interest in wage-increase permits (WIPs). However, MMT proponents are wrong to claim that a JGP is not afflicted by the conflict inflation problem, and they are doubly wrong to be dismissive of Lerner's later concerns that prompted his WIPs proposal.

Those multiple adverse considerations suggest it may be better to use and strengthen existing policy modalities to secure stable full employment. Such modalities include structural measures to improve income distribution (for example, restoring worker bargaining power and reinvigorating progressive taxation) so as to rebuild the aggregate demand generation process, combined with strengthened and improved counter-cyclical stabilization policy (for example, planned counter-cyclical infrastructure spending,

30. There is a significant literature that is critical of the ELR/JGP proposal which includes Aspromorgous (2000), Palley (2001; 2018b; 2018c), Sawyer (2003; 2005), and Seccareccia (2004).

31. Note that this income distribution conflict problem is less present in an indexed real minimum wage because there is no guaranteed offer of a job at that real wage. A real minimum wage only affects the terms of labor supply. A real JGP wage affects both labor supply and labor demand. 
counter-cyclical interest rate policy, plus counter-cyclical asset and credit market policy based on asset-based reserve requirements. ${ }^{32}$

\section{THE HISTORY OF MONEY ${ }^{33}$}

The third leg of MMT's triad of arguments in Figure 1 refers to the history of money. That leg is essentially rhetorical and it is not as important as the arguments about either the macroeconomics of money-financed budget deficits or the JGP. It is there to enlist monetary history in support of MMT's macroeconomic argument, which is why monetary history figures so prominently in MMT's narrative (Wray 1998; 2015; 2019). The claim is the history of money is 'chartal,' by which is meant money is a token created and spent by government, which then circulates as money.

Unfortunately, monetary history does not support MMT's claim, and it is especially confounded by the fact that for most of the past 2000 years money has involved gold and silver bullion. Metallic money is the exact opposite of chartal money since government cannot create gold and silver money out of thin air. In a metallic system, government must first tax or borrow to acquire money to spend, which is completely contrary to MMT's fundamental macroeconomic logic. As Rochon and Vernengo (2003) argue, even though modern money ends up being Chartalist, its origins are not.

The US only became fully chartal on 13 August 1971 when President Nixon suspended official convertibility (that is, the right of foreign governments to convert dollars into gold). That suspension undoubtedly gave US policymakers an important additional degree of policy freedom. However, the other constraints on budget policy imposed by existing debts, existing large federal expenditures, financial markets, and the Phillips curve all carried over the day after suspension.

Indeed, the financial experience after the suspension of official convertibility confirms the existence of those constraints. Thus, the 1970s' weakening of the dollar and higher inflation can be partly attributed to financial markets' response to the end of dollar convertibility, which shows financial markets do respond to public finance developments. ${ }^{34}$

\section{CONCLUSION: MMT AS POLITICAL POLEMIC}

This paper has examined the theoretical foundations of MMT. It began with a discussion of what MMT is not about. It is not about Keynesian economics, the effectiveness of deficit-financed fiscal policy, endogenous money, stock-flow consistent modeling,

32. Crocker (2020), who is a proponent of MMT, advocates a universal basic income (UBI) rather than a JGP. In addition to sharing the critics' concerns with a JGP, Crocker argues current unemployment is due to insufficient AD owing to income inequality. A UBI explicitly targets more equal income distribution, making it a superior policy instrument compared to a JGP.

33. The arguments in this section are drawn from Palley (2018a).

34. MMT tends to dismiss the problems of the US dollar in the 1970s, as if current favorable conditions are a permanent fact of nature. The dollar's difficulties in the 1970s are evidence that even the US can be subject to international constraints, though that may be difficult to recognize now given the dollar's current hegemonic standing. Ironically, were the US to formally adopt MMT as the basis for budget policy, that shift might even trigger financial disruption, inflation, and dollar weakness. That possibility is yet another example of the importance of taking account of policy regime in macroeconomic analysis, which is something MMT systematically fails to do. 
or macroeconomic sectoral balance analysis. Instead, MMT's major unique claim is that sovereign governments, with flexible exchange rates and without foreign currency debt, are financially unconstrained owing to their ability to issue money.

The paper showed MMT oversimplifies the macro economy and exaggerates policy capabilities. All macroeconomic models are highly simplified representations of reality. MMT takes the standard Keynesian macro model and further assumes away the real world challenges of the economy and policymaking. The resulting oversimplified static model makes it look as if sovereign government is financially unconstrained and full employment without inflation is an easy reach for policy. Once those oversimplifications are walked back, MMT's claim dissolves and MMT reduces back to a version of Old Keynesianism.

Despite MMT's analytical economic deficiencies, it has made huge advances as popular political polemic. Its success is due to two factors. First, MMT has a simple and clear narrative. Second, events have exposed the neoliberal lie regarding the ineffectiveness of and lack of financial space for fiscal policy, creating an opening in public discourse which MMT has seized.

As regards narrative, MMT's printing press economics has provided a simple counter to neoliberalism's claim that government has no financial space because it is akin to a private household. MMT's identification of the financial space provided by the power to create money exposes the falsity of the household analogy. ${ }^{35}$

Unfortunately, MMT exaggerates and stretches things. That should be no surprise: sometimes a little nonsense is needed to beat nonsense. Political success requires message simplification, and simplification involves cutting details. Thus, the ability to create money is transformed into the notion of government being financially unconstrained and not needing taxes or bonds to finance spending.

MMT's political polemic works best in the US, where government is in a special position owing to strong current economic conditions, the current low inflation climate, and the unique position of the dollar as global reserve currency which diminishes problems associated with trade deficits and exchange rates. However, the polemic is largely unpersuasive to economists in Latin America and emerging market economies. Those economies do not have the characteristics of the US, and their governments are visibly policy-constrained by financial markets and foreign exchange concerns.

The success of MMT's polemic poses difficulties for progressive economists. On the one hand, the polemic is useful for advancing progressive economic policy so that undermining it would be a step back politically. On the other hand, MMT's economics is oversimplified and exaggerated. That creates a dilemma that often afflicts the middle ground, which gets squeezed by simplistic extremes that have persuasive traction in political discourse.

In the fiscal policy debate, the extremes are MMT and austerity. The former argues government is financially unconstrained, while the latter argues government is akin to a household and has little financial space. Both are wrong. For progressive Keynesians, in the current political moment, the dilemma is that mere admission of the existence of financial constraints on government may facilitate neoliberal austerity which has done such damage over the past two decades.

35. The principal reasons the analogy is false are: (i) government can raise taxes to pay its bills while households cannot; (ii) government can issue money to pay its bills; and (iii) government lives forever whereas householders do not, so that government's income stream is far longer. 


\section{REFERENCES}

Akerlof, G.A., W.T. Dickens, and G.L. Perry (2000), 'Near-rational wage and price setting and the long run Phillips curve,' Brookings Papers on Economic Activity, 1, 1-60.

Aspromorgous, T. (2000), 'Is an employer-of-last-resort policy sustainable? A review article,' Review of Political Economy, 12(2), 141-155.

Aspromorgous, T. (2014), 'Keynes, Lerner, and the question of public debt,' History of Political Economy, 46(3), 409-433.

Blinder, A.S. and R.M. Solow (1973), 'Does fiscal policy matter?', Journal of Public Economics, 2, 319-337.

Brueing, M. (2019), 'What's the point of modern money theory?,' People's Policy Project, 24 February, available at: https://www.peoplespolicyproject.org/2019/02/24/whats-thepoint-of-modern-monetary-theory/.

Cagan, P. (1956), 'The monetary dynamics of hyperinflation,' in M. Friedman (ed.), Studies in the Quantity of Money, Chicago: Chicago University Press, pp. 25-117.

Christ, C.F. (1968), 'A simple macroeconomic model with a government budget restraint,' Journal of Political Economy, 76, 53-67.

Crocker, G. (2020), Basic Income and Sovereign Money: The Alternative to Economic Crisis and Austerity Policy, Cham, Switzerland: Palgrave Pivot.

Eichengreen, B. (2011), Exorbitant Privilege: The Rise and Fall of the Dollar and the Future of the International Monetary System, Oxford: Oxford University Press.

Epstein, G. (2019), 'The institutional, empirical, and policy limits of modern money theory,' Working Paper No 481, Political Economy Research Institute, University of Massachusetts, Amherst, March.

Forstater, M. and W. Mosler (2005), 'The natural rate of interest is zero,' Journal of Economic Issues, 39, 535-542.

Friedman, M. (1961), 'The lag in effects of monetary policy,' Journal of Political Economy, 69(October), 447-466.

Godley, W. (1999), 'Seven unsustainable processes: medium-term prospects and policies for the United States economy and the world,' Strategic Analysis, January, Annandale-on-Hudson, NY: Levy Economics Institute of Bard College.

Haliassos, M. and J. Tobin (1990), 'The macroeconomics of government finance,' in B.M. Friedman and F.H. Hahn (eds), Handbook of Monetary Economics, Vol. II, Amsterdam: North-Holland, pp. 887- 959.

Henwood, D. (2019), 'Modern monetary theory isn't helping,' Jacobin, 21 February, available at: https://www.jacobinmag.com/2019/02/modern-monetary-theory-isnt-helping.

Jayadev, A. and J.W. Mason (2018), 'Mainstream macroeconomics and modern money theory: what really divides them?,' Institute for New Economic Thinking, 6 September, available at: https://www.ineteconomics.org/perspectives/blog/mainstream-macroeconomics-and-modernmonetary-theory-what-really-divides-them.

Kalecki, M. (1943), 'Political aspects of full employment,' Political Quarterly, 14(4), 322-330.

Kelton, S. (1999), 'Functional finance: what, why, and how?,' Working Paper No 287, Annandale-on-Hudson, NY: Levy Economics Institute of Bard College.

Kelton, S. (2019), 'Modern money theory is not a recipe for doom,' Bloomberg, 21 February, available at: https://www.bloomberg.com/opinion/articles/2019-02-21/modern-monetarytheory-is-not-a-recipe-for-doom.

Kelton, S., A. Bernal, and G. Garlock (2018), 'We can pay for a Green New Deal,' Huffington Post, 30 November.

Krugman, P. and L. Taylor (1978), 'Contractionary effects of devaluation,' Journal of International Economics, 8, 445-456.

Lavoie, M. (2014), 'The monetary and fiscal nexus of Neo-Chartalism: a friendly critique,' Journal of Economic Issues, 47(1), 1 -32.

Lavoie, M. (2019), 'Modern monetary theory and post-Keynesian economics,' Real World Economics Review, 89, 97-108. 
Lerner, A.P. (1943), 'Functional finance and the federal debt,' Social Research, 10, 38-51.

Lerner, A.P. (1951), Economics of Employment, New York: McGraw-Hill.

Lerner, A.P. (1977), 'From pre-Keynes to post-Keynes,' Social Research, 44(3), 387-415.

Lerner, A.P. (1978), 'A wage-increase permit plan to stop inflation,' Brookings Papers on Economic Activity, 2, 491-505.

Lucas, R.E., Jr (1976), 'Econometric policy evaluation: a critique,' in K. Brunner and A. Meltzer (eds), The Phillips Curve and Labor Markets, Vol. 1, Carnegie-Rochester Conference Series on Public Policy, Amsterdam: North-Holland, pp. 19-46.

Mankiw, N.G. (2020), 'A skeptic's guide to modern monetary theory,' NBER Working Paper No 26650, January.

Michell, J. (2019), 'Understanding MMT,' Critical Macro Finance blog, 6 February, available at: https://criticalfinance.org/2019/02/06/misunderstanding-mmt/.

Mitchell, W.F. and W. Mosler (2001), 'Unemployment and fiscal policy,' in W. Mitchell and E. Carlson (eds), Unemployment: The Tip of the Iceberg, Sydney: The Center for Applied Economic Research.

Mitchell, W., L.R. Wray, and M. Watts (2019), Macroeconomics, London: Red Globe Press.

Mosler, W. (1996), Soft Currency Economics II: What Everyone Thinks That They Know About Monetary Policy is Wrong, Christiansted, St. Croix: Valance.

Nersisyan, Y. and L.R. Wray (2010), 'Does excessive sovereign debt really hurt growth? A critique of This Time Is Different, by Reinhart and Rogoff,' Working Paper No 603, Annandaleon-Hudson, NY: Levy Economics Institute of Bard College.

Nersisyan, Y. and L.R. Wray (2019), 'How to pay for the Green New Deal,' Working Paper No 931, Annandale-on-Hudson, NY: Levy Economics Institute of Bard College.

Nersisyan, Y. and L.R. Wray (2020), 'The myth of helicopter money,' Project Syndicate, 20 April.

Palley, T.I. (1998), 'The twin circuits: aggregate demand and the expenditure multiplier in a monetary economy,' Review of Radical Political Economics, 30(September), 95-104.

Palley, T.I. (2001), 'Government as employer of last resort: can it work?,' Industrial Relations Research Association, 53rd Annual Proceedings, 269-274.

Palley, T.I. (2003), 'The backward bending Phillips curve and the minimum unemployment rate of inflation (MURI): wage adjustment with opportunistic firms,' The Manchester School, 71(1), 35-50.

Palley, T.I. (2015a), 'Money, fiscal policy, and interest rates: a critique of modern money theory,' Review of Political Economy, 27(1), 1-27.

Palley, T.I. (2015b), 'The critics of modern money theory (MMT) are right,' Review of Political Economy, 27(1), 45-61.

Palley, T.I. (2018a), 'The evolution of money debate: functionalism versus Chartalism, Schumpeterian dynamics, Gresham's fallacy, and how history constrains public finance,' FMM Working Paper No 24, October, Dusseldorf, Germany: Institute for Macroeconomics (IMK).

Palley, T.I. (2018b), 'Government spending in the income-expenditure model: spending composition, the multiplier, and job guarantee programs,' FMM Working Paper No 30, July, Dusseldorf, Germany: Institute for Macroeconomics (IMK).

Palley, T.I. (2018c), 'Job guarantee programs: careful what you wish for,' Social Europe, 14 September, available at: https://www.socialeurope.eu/job-guarantee-programs-carefulwhat-you-wish-for.

Palley, T.I. (2019), 'Macroeconomics vs. modern money theory: some unpleasant Keynesian arithmetic and monetary dynamics,' Real World Economics Review, 89(September), 33-40.

Rochon, L.-P. and M. Vernengo (2003), 'State money and the real world: or chartalism and its discontents,' Journal of Post Keynesian Economics, 26(1), 57-67.

Rogoff, K. (2019), 'Modern monetary nonsense,' Project Syndicate, 4 March.

Rowthorn, R.E. (1977), 'Conflict, inflation, and money,' Cambridge Journal of Economics, 1, 215-239.

Sawicky, M. (2019), 'The best way to argue against PAYGO,' In These Times, 4 January.

Sawyer, M. (2003), 'Employer of last resort: could it deliver full employment and price stability?', Journal of Economic Issues, 37, 881-907. 
Sawyer, M. (2005), 'Employer of last resort: a response to my critics,' Journal of Economic Issues, 39, 256-264.

Seccareccia, M. (2004), 'What type of full employment? A critical evaluation of the government as employer of last resort policy proposal,' Investigacion Economica, 63, 15-43.

Tinbergen, J. (1952), On the Theory of Economic Policy, Amsterdam: North-Holland.

Tobin, J. (1963), 'Deficit, deficit, who's got the deficit?', New Republic, 19 January, 10-12.

Tobin, J. (1969), 'A general equilibrium approach to monetary theory,' Journal of Money, Credit and Banking, 1, 15-29.

Tobin, J. (1982), 'Money and finance in the macroeconomic process,' Journal of Money, Credit and Banking, 14, 171-204.

Tymoigne, E. and L.R. Wray (2015), 'Modern money theory: a reply to Palley,' Review of Political Economy, 27(1), 24-44.

Wray, L.R. (1998), Understanding Modern Money: The Key to Full Employment and Price Stability, Cheltenham, UK and Lyme, NH: Edward Elgar Publishing.

Wray, L.R. (2007), 'A Post-Keynesian view of central bank independence, policy targets and the rules-versus-discretion debate,' Working Paper No 510, Annandale-on-Hudson, NY: Levy Economics Institute of Bard College.

Wray, L.R. (2015), Modern Money Theory: A Primer on Macroeconomics for Sovereign Monetary Systems, 2nd edn, Basingstoke, UK: Palgrave Macmillan.

Wray, L.R. (2019), 'Alternative paths to modern money theory,' Real World Economics Review, 89(September), 5-21. 